\title{
Assessing the conservation status of tree fern Cibotium arachnoideum (C. Chr.) Holttum
}

\author{
TITIEN NGATINEM PRAPTOSUWIRYO^ \\ Research Center for Plant Conservation and Botanic Gardens (Bogor Botanic Gardens), Indonesian Institute of Sciences. \\ J1. Ir. H. Juanda No. 13, Bogor 16022, West Java, Indonesia. Tel.: +62-251-8322187. Fax.: +62-251-8322187, `email: tienpferns@ gmail.com
}

Manuscript received: 12 January 2020. Revision accepted: 9 March 2020

\begin{abstract}
Praptosuwiryo TN. 2020. Assessing the conservation status of tree fern Cibotium arachnoideum (C.Chr.) Holttum. Biodiversitas 21: 1379-1384. Cibotium arachnoideum (C.Chr.) Holttum (Cibotiaceae), is a large terrestrial fern with an upright or prostrate rhizome having densely shining reddish-brown of rigid hairs and one or two pairs of sori with two indusia forming a small cup on each lamina-segment. This tree fern is a rare species and strictly distributed in the Malesian region. The study aims to assess the conservation status of $C$. arachnoideum by using the 2012 IUCN Red List Catagories and Criteria (version 3.1.). Population size was estimated and observed both based on specimens deposited at the Herbarium Bogoriense (BO) and field studies in Sumatra. The area of occupancy (AOO) of this species is $44 \mathrm{~km} 2$. Cibotium arachnoideum is occurred in severely fragmented locations in the West Malesian region, in 2 locations, viz. Sumatra and Borneo. Sumatra has only two subpopulations, and Borneo has nine subpopulations. The number of mature individuals was only found 372 in one location of North Sumatra and 19 individuals in one location of Bengkulu. Therefore, C. arachnoideum is proposed as an endangered species, En: B2ab (i,ii,iii) + C2a (ii).
\end{abstract}

Keywords: Area of occupancy (AOO), Cibotium arachnoideum, conservation status, extent of occurrence (EOO), tree fern

\section{INTRODUCTION}

As stated in global conservation priority in the GSPC Target 2 of the objective 1, assessing a conservation status of plant species is very important, because it is a fundamental step to guide conservation action. This target is critical to reaching the Target 7 and 8 of the GSPC programs (GSPC 2002). Conservation status assessments are intended to be policy-relevant and can be used to set a baseline conservation planning and priority setting processes (García-Criado et al. 2017). A comprehensive list of species of conservation concern would be useful in determining those species in need of further study and support development of management plans for their survival (Miller et al. 2012) and sustainable uses.

The IUCN Red List of Threatened Species (http: $/ /$ www.iucnredlist.org) is the most comprehensive and authoritative resource dealing with the conservation status of living organisms (Butchart et al. 2004, 2005; Rodrigues et al. 2006). The Red List is the product of a flexible system that can use five criteria to assign each species to a category indicating whether it is extinct, or included in one of three increasingly severe threatened categories, from vulnerable to endangered, or maybe of least concern (IUCN 2012). The conservation status of a species can be assessed based on the current status of species, take into account the history of species, or may speculate about future decline (IUCN 2012; Burgman et al. 2000).

Ferns and lycophyte flora of Asia are remarkably abundant. It estimated that 4500 species of ferns and lycophyte flora, or more than one-third of the world's diversity, occurs in Southeast Asia (Moran 2008), and 2197 species of them are existed in Indonesia (LIPI 2014). The publications Flora Malesiana series II (Pteridophytes) do not yet even cover half of the species that occur in the region, and it would need a considerable amount of time for their completion (Roos 1996). Meanwhile, the speed of deforestation in Asia, including in Southeast Asia, is remarkably high (Sodhi and Brook 2006). Ferns and lycophytes, which are the major components of the forest understorey, are undoubtedly under threat (Brummitt 2016). Ferns and lycophytes have faced a new kind of risk as humans have destroyed the natural habitats and unparalleled species extinction (Pimm and Raven 2000). A list of narrowly distributed Asian pteridophyte taxa towards an assessment of globally threatened species has been published yet. Of the total 886 taxa (835 species and 51 infraspecific taxa) enumerated, 577 occur in Southeast Asia, 215 in East Asia, and 101 in South Asia (Ebihara et al. 2012).

Tree ferns are keystone species of a wet tropical forest as they are often dominating the sub-canopy layer with tall trunks and crowns of large fronds (Walker and Aplet 1994, Durand and Goldstein 2001, Roberts et al. 2005). Cibotium Kaulfuss is giant tree ferns with usually prostrate or erect trunk-like rhizome with the apex of rhizome and stipes which are protected by a thick cover of long slender golden shining yellow-brown hairs. This genus is also characterized by two indusia joined together for a short distance at the base and forming a small cup around the receptacle of the sorus (Holttum 1963). This genus has a member of about 12 species, which is distributed in Central America, Mexico, Hawaii, Assam to southern China, Western Malesia, and Philippines (Holttum 1963; Hassler 
and Swale 2002). Three species are occurring in the Malesian region, namely, C. arachnoideum (C. Chr.) Holttum, C. barometz (L.) J. Sm., and C. cumingii Kunze (Holttum 1963).

In Indonesia, we recognize only two species of Cibotium, namely $C$. arachnoideum and $C$. barometz. Recently field studies on Cibotium in Sumatra, Indonesia, revealed that populations of $C$. arachnoideum are restricted from two severely fragmented locations, while $C$. barometz is more widely distributed (Rugayah et al. 2009; Praptosuwiryo et al. 2011, 2017). The national conservation status of $C$. barometz has been assessed. This species is included in the vulnerable category (VU A4cd) (Praptosuwiryo and Rugayah 2017); meanwhile, the conservation status of $C$. arachnoideum has not been reported yet. This study aims to assess the conservation status of $C$. arachnoideum.

\section{MATERIALS AND METHODS}

\section{Status assessment}

The conservation status of $C$. arachnoideum was assessed using the 2012 IUCN Red List Categories and Criteria (version 3.1). The majority of threatened ferns and lycophyte species have been evaluated for the IUCN for Plants using IUCN Criterion B and therefore categorized based on the geographic range (Brummitt et al. 2016). Based on the population size and distribution data collected from the field, it is estimated that the conservation status of C. arachnoideum falls into the category of endangered under IUCN B and C criteria.

\section{Specimen examination}

In ferns and lycophytes, for most species, the most comprehensive, easily accessible, and reliable information representing the known distribution of that species and on which a conservation assessment could be based was accurately-identified herbarium specimens. Herbarium records were used to identify provincially uncommon, rare, and very rare plant taxa recorded in an area (MacDougall et al. 1998). Herbarium specimens are verifiable records, indicating the existence of a species at a given time and place (Brummitt et al. 2016). The dried materials of $C$. arachnoideum deposited at BO (Herbarium Bogoriense) which were used in assessing the conservation status of the species as follows.

Specimens examined: - East Kalimantan: Krayan, north of Long Bawan, En route from Para ya to Sinar baru. $115^{\circ} 45^{\prime}$ E, $4^{\circ}$ N. 1150 m. 17 July 1981. M. Kato, M. Okamoto, dan E. B. Walujo - B.9088; Krayan, North of Long Bawan, Sinar Baru. $115^{\circ} 45^{\prime}$ E, $4^{\circ}$ N. 1150 m. 4 August 1981. M. Kato, M. Okamoto, dan E. B. Walujo B.106; Krayan, north of Long Bawan, Mount Buduk Rakik; Krayan, north of Long Bawan, Mt Batu Harun. $115^{\circ} 47^{\prime}$ E, 4ㅇ' N. 1150 - 1650 m. 25 July1981. M. Kato, M. Okamoto, dan E. B. Walujo - B.9858; Krayan, north of Long Bawan, Mt Leputung. 355' N, 115²40' E. 900 - 1375 m. M. Kato, M. Okamoto, K. Ueda dan E. B. Walujo B.8069; Krayan, south of Long Bawan, Mt Paris. $3^{\circ} 50^{\prime} \mathrm{N}$, $115^{\circ} 40^{\prime}$ E. 900 - 1050 m. M. Kato, M. Okamoto, K. Ueda dan E. B. Walujo - B.7384; Krayan, West to Long Bawan, Near Pa Nanado. 16 July1981. 35' N, 115³5' E. 1000 1200 m. K. Ueda dan D. Darnaedi - B.8553 (D. 2495); Krayan, south of Long Bawan, Mt Buduk Rian. 115²' E, $3^{\circ} 50^{\prime}$ N. 900 - 1500 m. 31 August 1981. M. Kato, M. Okamoto, dan E. B. Walujo-B.11425; Krayan, north of Long Bawan, South foot of Mt Batu Linanit, 115 40' E, $4^{\circ} 8^{\prime}$ N, 1100 m. M. Kato, M. Okamoto, dan E. B. Walujo s.n.; Sarawak, Mt Kinabalu, Eastern Shoulder. 6005' N, 116³6'-40’ E. 2500 ft. 26 August 1961. W. L. Chef, E. J. H. Corner, A. Stainton-998 (BO).

\section{Calculating of Extent of Occurrence (EOO) and Estimating Area of occupancy (AOO) using GeoCAT (Geospatial Conservation Assessment Tool)}

The geographical and ecological data contained in the specimen labels of herbarium collections are an invaluable source of information for EOO, AOO, and fragmentation (Herna'ndez and Navarro 2007). AOO is the area occupied by a taxon within its more general EOO (IUCN 2012), and it is usually taken as a measure of species distribution size. The AOO of species is one of the more commonly used parameters in Red List assessments (Herna'ndez and Navarro 2007). Specific measures of species' geographic range (EOO) and AOO were used in carrying out IUCN Red List assessments under Criterion B.

GeoCAT is utilized to figure out the AOO and EOO. It is a web tool that utilizes primary biological data for semiautomated IUCN Red List assessment and analysis. The web address available at https: //www.kew.org/science/ourscience/projects/geocat-geospatial-conservation-assessmenttool. This web tool is an open-source to performs rapid geospatial analysis to ease the proses of Red Listing species (Bachman et al. 2011). The guide for using the GeoCAT tool is available on the website https: //www.kew.org/science/collections-and-resources/data-anddigital/tools/geocat-help.

\section{RESULTS AND DISCUSSION}

Taxonomic Notes. Cibotium arachnoideum (Figure 1.) was established by Holttum (1963). It is tree fern species belong to the family Cyatheaceae sensu Holttum (1963). Smith et al. (2006) placed Cibotium in its own family, Cibotiaceae, based on the distinction of its spore morphological characteristics in addition to molecular data. 


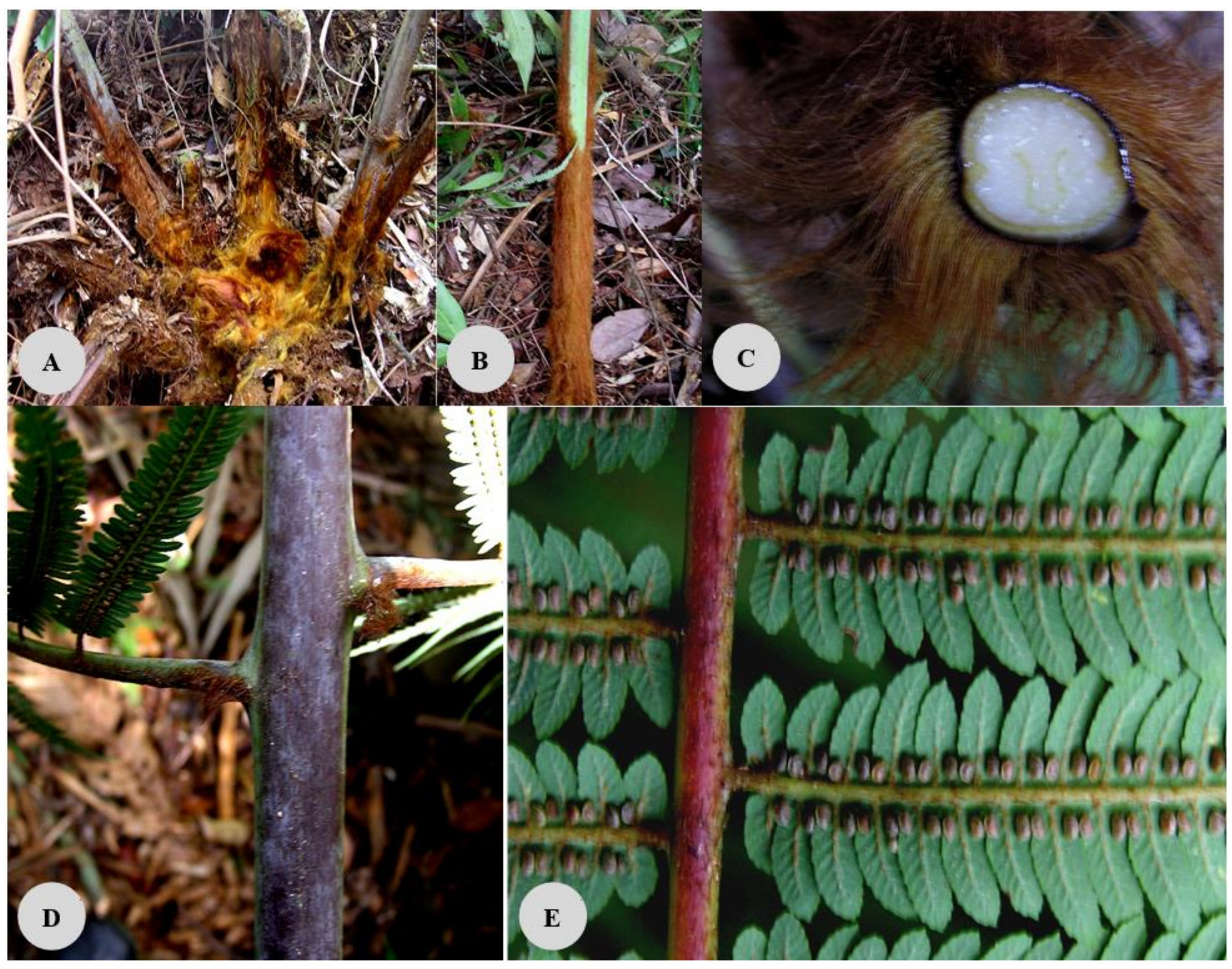

Figure 1. Cibotium arachnoideum (C.Chr.) Holttum. A. Rhizome with stipes covered by densely shining reddish-brown of rigid hairs; B. Basal stipe; C. Transversal cross-section of basal stipe; D. Middle rachise, showing the remains hairs attaching at the adjacent between rachise and costa. E. Parts of pinnulae with its fertile lobes bearing 1-2 rows of sori covering by reddish-purple of indusia

Cibotium arachnoideum is similar to $C$. barometz. However, the two species can be distinguished by three character combinations: (i) the existence of the hairs on costa and costule of the adult fronds; (ii) the incision of pinnulae segments; and (iii) the pair number of sori. $C$. arachnoideum has the remains hairs attaching on the costa and costule; rigid reddish appressed hairs always present, and sometimes abundant, small flaccid hairs present on lower surface of lamina between veins; largest pinnules 15$26 \mathrm{~mm}$ wide, pinnules on the basiscopic side of lower pinnae much shorter than those on the acroscopic side; always have two pairs of sori on large fronds. Meanwhile, $C$. barometz has no persistent hairs on the costa and costule; small flaccid hairs absent on lower surface of lamina between veins; largest pinnules 20-35 mm wide, pinnules on the two sides of a pinna not significantly different in length, hairs on lower surface of costae and costules almost always thin and flaccid and never spreading; sori 2 - 12 pairs on each pinnule-lobe of larger fronds (Praptosuwiryo et al. 2011). Those character combinations met with the specimens described by Holttum (1963).
Cibotium arachnoideum also has a morphological similarity to $C$. cumingii, but $C$. cumingii fronds are smaller than those of $C$. arachnoideum and its pinnule ca. $180 \mathrm{~mm}$ in length and $22 \mathrm{~mm}$ in width. The pinnae of the two species are asymmetrical, and the basiscopic side is shorter than the acroscopic side. The number of sori in $C$. cumingii is either 1 to 2 pairs and it is located at the base of each fertile segment of a pinnule. The indumentum of the lower surface of costae and costules is variable with some stiff spreading hairs, which is pale or reddish (Maideen et al. 2018).

Geographic range. Cibotium arachnoideum is native to Indonesia and Malaysia and strictly distributed in the Malesian region, namely in Central and South Sumatra, Sarawak, and North Borneo (Holttum 1963). Based on the herbarium specimen records in 1981, it suspected that this species is still occurring in East Kalimantan (Indonesia). Population studies for C. barometz conducted in 2008 at Bengkulu (central Sumatra) and North Sumatra found the small population of $C$. arachnoideum in two localities (Praptosuwiryo and Wardani 2008; Praptosuwiryo et al. 2011). 


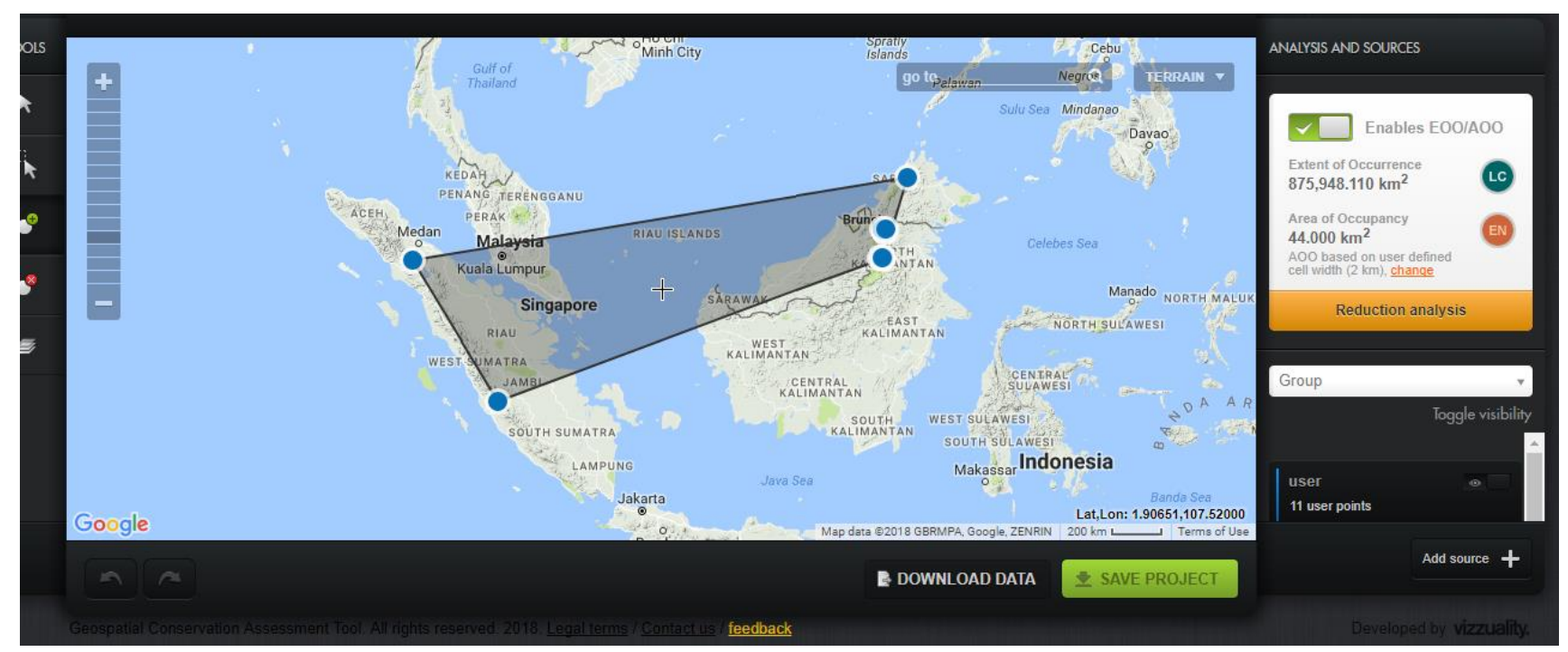

Figure 2. EOO and AOO of Cibotium arachnoideum in the Malesian region established by using GeoCAT (geocat.kew.org)

EOO and AOO. Based the latitude and longitudes data compiled from specimen labels of the herbarium housed at BO and the direct observation of $C$. arachnoideum in Sumatra (Praptosuwiryo and Wardani 2008; Praptosuwiryo et al. 2011) the distribution map of $C$. arachnoideum is established, and the EOO and AOO are calculated (Figure 2).

Population size. The population size of $C$. arachnoideum of Sumatra is described. Praptosuwiryo et al. (2011) recorded one specimen of Cibotium collected from North Sumatra, which housed at Herbarium Bogoriense (BO). It was compiled by H. Surbeck on 30 May 1941 (No. Coll.: H. Surbeck 114), from South Sibuctan, Lae Pondom, $1100 \mathrm{~m}$, the edge of primary forest. This collection was identified as $C$. barometz. The correct name of this record is $C$. arachnoideum. There was no population size information written on the label. Praptosuwiryo (2011) reported the population size of $C$. arachnoideum of Lao Pondom protected area, in the year of 2009. There were only 372 mature individuals recorded in 2,500 square meters. Lao Pondom is the same name for Lae Pondom. It is located in Merek Subdistrict, Karo district, North Sumatra.

Praptosuwiryo and Wardani (2008, unpublished data) reported the existence of the population of $C$. arachnoideum at Blok 40 of Bukit Daun Mas, Kayu Manis Country, Selupu Rejang Subdistrict, Rejang Lebong District, Bengkulu Province, Sumatra. Formerly, Praptosuwiryo and Wardani (2008, unpublished data) reported this species as a variant $C$. barometz. There were only 19 mature individuals of $C$. arachnoideum recorded in 100,000 m square areas of Bukit Daun Mas.

Currently, information on the population of $C$. arachnoideum from Borneo is lack. The historical records of this species on the island have been reported, but their quantitative population data were not mentioned. Holttum (1963), in the Flora Malesiana, noticed that $C$. arachnoideum was abundant in the secondary forest of Mt. Kinabalu. Labels of the specimen records of $C$. arachnoideum collected by Kato et al. in July 1982, from nine localities of Krayan, East Kalimantan, at the altitude between 900 - $1650 \mathrm{~m}$ asl, did not mention the population sizes. Parris et al. (1992) reported that C. arachnoideum occurred in Mt. Kinabalu at 900-1200 m asl.

Current population trend. The current population trend is suspected of being decreasing. In Sumatra, the habitat of $C$. arachnoideum is located in the disturbed protected forest, Lae Pondom Protected Forest, North Sumatra. Forest encroachment and illegal logging in Lae Pondom Protected area were quite widespread in 2018, tens of hectares of the protected areas have been deforested.

Habitats and ecology. In Lao Pondom Protected Forest, C. arachnoideum occurs at elevation range from 1740-1770 $\mathrm{m}$ sea level. This species grows on a range temperature of $23-23.5^{\circ} \mathrm{C}$, moist condition ( $\mathrm{RH} \pm 80 \%$ ), soil type of sandy quartz-rockery with dust or clay soil, soil acidity of 5.8, humus soil depth 3-4 cm, leaves litter depth $2.5-12.5 \mathrm{~cm}$. It grows on the hill with $0-80 \%$ of slopes (Praptosuwiryo et al. 2011).

In North Sumatra, C. arachnoideum is growing among the terrestrial fern species of Dipteris conjugata Reinw., Dicranopteris linearis (Burm. f.) Underw., Blechnum sp., Pyrrosia sp., Hymmenophyllum sp., Hystiopteris stipulacea (Hook.) Copel. Phymatodes sp. and Elaphoglossum sp. (Praptosuwiryo et al. 2011). In Mt. Kinabalu, Borneo, $C$. arachnoideum usually grows in cultivated areas among Pteridium esculentum and members of Gleicheniaceae (Parris et al. 1990).

Ecological studies in North Sumatra, in 2009 and 2015, revealed that $C$. arachnoideum would survive after land clearing. The surviving remaining rhizomes will grow new shoots. In Mount Kinabalu, at ca. 1000 m s.l., this species occurred on steep slopes, which were periodically cleared by burning for cultivation, apparently surviving the burning (Holttum 1963). The survival of $C$. arachnoideum towards the land clearing or burning has also been reported by Parris et al. (1992) on steep ladangs (fields) of Mt. Kinabalu, at 900-1200 m asl. 
Uses. The local people surrounding Mount Kinabalu use the soft hairs of $C$. arachnoideum for staunching bleeding wounds (Parris et al. 1992). For the local people in Sumatra, especially in North Sumatra, the uses of $C$. arachnoideum may be similar to $C$. barometz. As stated in some literature (see Ong and Nordiana 1999, Praptosuwiryo 2003), C. barometz is used as a medicinal and ornamental plant. It is suspected that in the field, the local people of North Sumatra do not differentiate the two species as two different plant species; therefore when harvesting the pilli cibotii (hairs of Cibotium), they mixed the hairs of the two species. The plants which are recognized as pakis kijang with golden yellow hairs are $C$. barometz, meanwhile, those with reddish-brown hairs are C. arachnoideum (Holttum 1963). The native people of North Sumatra stated that pakis simpey or pakis emas or pakis kijang (the vernacular name of Cibotium in Sumatra) consisted of two varian, gold yellow, and brown yellow.

Threats. Local action that potentially threatens the species is overexploitation and change of the land use. The population of $C$. arachnoideum in Sumatra is at risk. One of its habitat localities, in Lae Pondom Protected Forest, is deforested, as the protected forest is very close to the main road of North Sumatra. Meanwhile, the habitat of this fern in Bengkulu Province (Central Sumatra) is an industrial privacy forest. There was only one sub-population existed in that privacy industrial forest in Central Sumatra.

Conservation. Cibotium arachnoideum has been planted in the greenhouse of Bogor Botanic Gardens since 2008. The conservation actions that would be beneficial to the species should be performed. Studies dealing with the in vitro spore culture and somatic embryogenesis would be useful to facilitate the rapid propagation and conservation of the tree fern.

Red list assessment and rationale. Cibotium arachnoideum is tree fern with a wide range from Indonesia (Bengkulu and South Sumatra) to Malaysia (Sarawak and North Borneo). The estimated extent of occurrence (EOO) is $875,948.110 \mathrm{~km} 2$ ), exceeding the values needed for a threatened category. Based on the EOO, $C$. arachnoideum is included in LC category; However, the distribution is not continuous in an imaginary boundary, which can be drawn to encompass all the occurrence of this species. In addition, the EOO shown in Fig. 2 covers a large area of ocean. The area of occupancy (AOO) of this species is $44 \mathrm{~km} 2$. It meets the criterion of $\mathrm{B}$, the area of occupancy estimated to be less than $500 \mathrm{~km}^{2}$, and estimates indicating at the subcriterion of $a$ and $b$, under sub subcriterion of $\mathrm{i}$, ii, and iii (IUCN 2012). It is therefore considered to be facing a very high risk of extinction in the wild.

Besides, the population size estimated to number fewer than 2,500 mature individuals (Criterion $\mathrm{C}$ ). The number of mature individuals reported was only 372 in one location of North Sumatra, and 19 individuals in one location of Bengkulu. Based on the observation in the two localities and inferring the degradation of the habitat, the population of $C$. arachnoideum will be continuing decline in numbers of mature individuals (Criterion $\mathrm{C} 2$ ), and it is included in the sub-criterion of a (Population structure in the form of ) under sub-criterion of ii, at least $95 \%$ of mature individuals in one subpopulation. Therefore the conservation status proposed for $C$. arachnoideum is En: B2ab (i,ii,iii) $+\mathrm{C} 2 \mathrm{a}$ (ii).

To conclude, the conservation status of $C$. arachnoideum has been assessed by using the 2012 IUCN Red List Categories and Criteria (version 3.1). The area of occupancy (AOO) of this species is $44 \mathrm{~km} 2$. Cibotium arachnoideum is occurred in severely fragmented locations in the West Malesian region, viz. Sumatra and Borneo. Sumatra has two subpopulations, and Borneo has only nine subpopulations. The recorded number of the mature individuals was only 372 in one location in North Sumatra and 19 in one location in Bengkulu. The conservation status proposed for C. arachnoideum is En: B2ab (i,ii,iii) + $\mathrm{C} 2 \mathrm{a}$ (ii). Currently, information on $C$. arachnoideum populations in Kalimantan and Sarawak is still lacking. In the future, the population study of $C$. arachnoideum in Borneo to gain a more comprehensive status needs to be carried out to provide further conservation policies.

\section{ACKNOWLEDGEMENTS}

This species was found unexpectedly during a study of the golden chicken fern Cibotium barometz in Sumatra funded by (i) DIPA of the Research Center for BiologyLIPI of the year 2008, (ii) A Grand-in-Aid for Scientific Research from The Ministry of Research and Technology, under The Program Insentif Peneliti dan Perekayasa LIPI TA 2009, and (iii) Program Riset Unggulan LIPI TA 2015. I thank Ir. Dwi Murti Puspitaningtyas, Sri Hartini, and Dr. Didit Okta Pribadi (Research Center for Plant Conservation and Botanic Gardens-LIPI) for accompanying me during the field study of C. barometz in North Sumatra in 2009 and Wita Wardani (Research Center for Biology-LIPI) for her cooperation on the field study of $C$. barometz in Bengkulu in 2008. Dr. Malin C. Rivers (Botanic Gardens Conservation International, Richmond, United Kingdom) has given some comments to improve this manuscript. I also thank Dr. Kusumadewi Sri Yulita (Research Center for Biology-LIPI) and Rosniati Apriani Risna (Research Center for Plant Conservation and Botanic Gardens-LIPI) for allowing me an opportunity to be a participant of the Red List Training and Workshop, on 27-28 ${ }^{\text {th }}$ February 2018 , in Bogor. I really thank the anonymous reviewers for their in-depth comments in my manuscript.

\section{REFERENCES}

Bachman S, Moat J, Hill AW, de la Torre, J Ben Scott. 2011. Supporting Red List threat assessments with GeoCAT: geospatial conservation assessment tool. ZooKeys 150: 117-126. DOI: 10.3897/zookeys. 150.2109 .

Brummitt N, Aletrari E, Syfert MM, Mulligan M. 2016. Where are threatened ferns found? Global conservation priorities for pteridophytes. J Syst Evol 54 (6): 604-616. DOI: 10.1111/jse.12224.

Burgman MA, Maslin BR, Andrewartha D, Keatley MR, Boek C, McCarthy M. 2000. Inferring threat from scientific collections: power test and an application to western Australian Acacia species. In: Ferson S, Burgman M (eds.). Quantitative Methods for Conservation Biology. Springer, New York. 
Butchart SHM, Stattersfield A, Bennun L, Shutes S, Akc'akaya H, Baillie J, Stuart S, Hilton-Taylor C, Mace G. 2004. Measuring global trends in the status of biodiversity: Red List Indices for birds. PLoS Biol 2 (12): e383. DOI: 10.1371/journal.pbio.0020383.

Butchart SHM, Stattersfield A, Baillie J, Bennun L, Stuart S, Akc'akaya H, Hilton-Taylor C, Mace G. 2005. Using Red List Indices to measure progress towards the 2010 target and beyond. Philos Trans R Soc 360: 255-268.

Durand IZ, Goldstein G. 2011. Photosynthesis, photoinhibition, and nitrogen use efficiency in native and invasive tree ferns in Hawaii. Oecologia 126: 345-354.

Ebihara A, Fraser-Jenkins CR, Parris BS, Zhang X-C, Yang Y-H, Chiou W-L, Chang H-M, Lindsay S, Middleton D, Masahiro Kato M, Praptosuwiryo TNg, Amoroso VB, Barcelona JF, Ranil RHG, Park CH, N. Murakami M, Hoya A. 2012. Rare and threatened Pteridophytes of Asia 1. An enumeration of narrowly distributed taxa. Bul Nat Nat Sci Series B (Botany) 38 (3): 93-119.

Grubb PJ. 2003. Interpreting some outstanding features of the flora and vegetation of Madagascar. Perspect Plant Ecol Evol Syst 6: 126-146.

García-Criado M, Väre H, Nieto A, Bento Elias R, Dyer R, Ivanenko Y, Ivanova D, Lansdown R, Molina JA, Rouhan G, Rumsey F, Troia A, Vrba J, Christenhusz MJM. 2017. European Red List of Lycopods and Ferns. IUCN, Brussels, Belgium.

GSPC. 2002. Global Strategy for Plant Conservation. Convention on Biological Diversity. Montreal, Quebec, Canada.

Hernandez HM, Navarro M. 2007. A new method to estimate areas of occupancy using herbarium data. Biodivers Conserv 16: 2457-2470. DOI 10.1007/s10531-006-9134-6.

Hassler M, Swale B. 2002. Family Dicksoniaceae genus Cibotium; World species list. http: //homepages.caverock.net.nz. Accessed: January 2017.

Holttum RE. 1963. Cyatheaceae. Flora Malesiana Ser II 1 (2): 65-176.

IUCN. 2012. IUCN Red List Catagories and Criteria: Version 3.1. Second edition Gland, Switzerland and Cambridge, UK.

LIPI (Lembaga Ilmu Pengetahuan Indonesia). 2014. Status Kekinian Keanekaragaman hayati Indonesia. Indonesian Institute of Sciences, Bogor. [Indonesian]

MacDougall AS, Loo JA, Clayden SR, Goltz JG, Hinds HR. 1998 Defining conservation priorities for plant taxa in Southeastern New Brunswick, Canada using herbarium records. Biol Conserv 86: 325 338.

Maideen H, Arbawi YAM, Khaduwi NM, Kamil NM. 2018. A systematic study on the genus Cibotium Kaulf. of Peninsular Malaysia. Malay Appl Biol 47 (3): 79-84.

Miller JS, Porter-Morgan HA, Stevens H, Boom B, Krupnick GA, Acevedo-Rodrıguez P, Fleming J, Gensler M. 2012. Addressing target two of the Global Strategy for Plant Conservation by rapidly identifying plants at risk. Biodivers Conserv 21: 1877-1887. DOI 10.1007/s 10531-012-0285-3
Moran RC. 2008. Diversity, biogeography, and floristics. In: Ranker TA, Haufler CH (eds.). Biology and Evolution of Ferns and Lycophytes. Cambridge University Press, New York.

Ong H, Nordiana M. 1999. Malay ethno-medico botany in Machang, Kelantan Malaysia. Fitoterapia. 70 (5): 502-513.

Parris BS, Beaman RS, Beaman JH. 1992. The plants of Mount Kinabalu. I. Ferns and fern allies. Royal Botanic Gardens, Kew.

Pimm SL, Raven P. 2000. Extinction by numbers. Nature 403: 843-845.

Praptosuwiryo TNg. 2003. Cibotium barometz (L.) J. Smith. In: de Winter WP, Amoroso VB (eds) Plant Resources of South-East Asia 15 (2) Cryptogams: Ferns and Fern Allies Backhuys, Leiden.

Praptosuwiryo TNg, Wardani W. 2008. Survei Cibotium barometz Bengkulu IV: Studi potensi, variasi morfologi dan monitoring regenerasinya secara vegetatif. Bidang Botani, Pusat Penelitian Biologi, LIPI. Laporan Teknis, Bogor. [Indonesian]

Praptosuwiryo TNg, Puspitaningtyas DM, Rugayah, Hartini S. 2010. Keragaman Paku Pohon Marga Cibotium di Sumatera. Prosiding Seminar Nasional Biologi UGM 2010. Faculty of Biology, Universitas Gadjah Mada, Yogyakarta.

Praptosuwiryo TNg, Pribadi DO, Puspitaningtyas DM, Hartini S. 2011. Inventorying of the tree fern genus Cibotium of Sumatra: Ecology, population size and distribution in North Sumatra. Biodiversitas 12 (4): 204-211.

Praptosuwiryo TNg, Puspitaningtyas DM, Pribadi DO, Rugayah. 2017. Population study of the golden chicken fern (Cibotium barometz (L.) J.Sm.) in Riau Province, Sumatra. J Trop Life Science 7 (2): 167-176.

Praptosuwiryo TNg, Rugayah. 2017. Cibotiaceae (Paku tiang-paku tiangan). In: Rugayah, Yulita KS, Arifiani D, Rustiami H, Girmansyah D (Eds), Tumbuhan Langka Indonesia: 50 tumbuhan terancam kepunahan. LIPI Press, Jakarta. [Indonesian]

Rodrigues ASL, Pilgrim J, Lamoreux J, Hoffmann M, Brooks T. 2006. The value of IUCN Red List for conservation. Trends Ecol Evol 21: 71-76.

Roos MC. 1996. Mapping the world's pteridophyte diversity - systematics and floras. In: Camus JM, Gibby M, Johns RJ (eds) Pteridology in Perspective; Proceedings of the Holttum Memorial Pteridophyte Symposium. Royal Botanic Gardens, Kew.

Rugayah, Praptosuwiryo TNg, Puspitaningtyas DM. 2009. Morphological variation of Cibotium barometz from West Sumatra. Proceedings on The International Conference on Biological Science. Faculty of Biology, Universitas Gadjah Mada, Yogyakarta.

Sodhi NS, Brook BW. 2006. Southeast Asian Biodiversity in Crisis. Cambridge University Press, Cambridge.

Smith AR, Pryer KM, Schuettpelz E. Korall P, Schneider H, Wolf PG. 2006. A classification of extant ferns. Taxon 55 (3): 705-731.

Walker LR, Aplet GH. 1994. Growth and fertilization responses of Hawaiian tree ferns. Biotropica 26: 378-383. 